\title{
Desulfovibrio bastinii sp. nov. and Desulfovibrio gracilis sp. nov., moderately halophilic, sulfate- reducing bacteria isolated from deep subsurface oilfield water
}

\author{
Michel Magot, ${ }^{1}$ Odile Basso, ${ }^{1}$ Christèle Tardy-Jacquenod ${ }^{2}$ \\ and Pierre Caumette ${ }^{1}$ \\ ${ }^{1}$ Université de Pau et des Pays de l'Adour, IBEAS, Laboratoire d'Ecologie Moléculaire, \\ EA3525, F-64013 Pau, France \\ 211 Place Garibaldi, F-42000 Saint Etienne, France
}

Correspondence

Michel Magot

michel.magot@univ-pau.fr
To understand the unusually fast corrosion failure of the Emeraude Oilfield (Congo) undersea oil pipeline in 1990, investigations into corrosion, water and oil chemistry, and microbiology were performed (Crolet \& Magot, 1996). Among other approaches, it was decided to isolate, characterize and identify all cultivable bacteria from a set of representative samples of production water. During this work, a large number of previously undescribed moderately halophilic, mesophilic, strictly anaerobic bacterial species have been isolated and described (Magot et al., 1997a, b; Ollivier et al., 1997; Ravot et al., 1997, 1999). Several strains of sulfate-reducing bacteria that could not be related to any known species on a phylogenetic basis have also been isolated. Among them, strains SRL4225 ${ }^{\mathrm{T}}$ and SRL6146 ${ }^{\mathrm{T}}$ were included in the genus Desulfovibrio; however, they are distant enough from known Desulfovibrio species, either phylogenetically or physiologically, to be described as novel species, for which we propose the names Desulfovibrio bastinii sp. nov. $\left(\mathrm{SRL}_{22} 5^{\mathrm{T}}\right)$ and Desulfovibrio gracilis sp. nov. (SRL6146 ${ }^{\mathrm{T}}$ ).

Published online ahead of print on 26 March 2004 as DOI 10.1099/ ijs.0.02977-0.

The GenBank/EMBL/DDBJ accession numbers for the 16S rRNA gene sequences of SRL4225 ${ }^{\top}$, SRL6146 ${ }^{\top}$ and Desulfovibrio longus DSM $6739^{\top}$ are AY359868, U53464 and AY359867, respectively.
Strain SRL4225 ${ }^{\mathrm{T}}$ was isolated from a water sample collected in the oil pipeline linking offshore production platforms of the Emeraude offshore oilfield (Congo) to onshore treatment facilities. The total bacterial count in the water sample (acridine orange direct count) indicated the presence of $2 \cdot 5 \times 10^{4}$ bacteria $\mathrm{ml}^{-1}$. Most probable number counts of sulfate-reducing bacteria were done as described previously (Magot et al., 1992) and showed the presence of $2.5 \times 10^{2}$ cultivable sulfate-reducing bacteria $\mathrm{ml}^{-1}$. In this experiment, the total salinity of the culture medium and the incubation temperature were adjusted so that they corresponded to the in situ conditions: total salinity of $53 \mathrm{~g} \mathrm{l}^{-1}$ and a temperature of $37^{\circ} \mathrm{C}$. Isolation of pure strains from the highest dilution of the most probable number count was done on solid medium in Petri dishes. Round black colonies (2-3 $\mathrm{mm}$ in diameter) were obtained after 2 weeks incubation. Several colonies were picked and their isolation was repeated twice. Cell morphology and restriction patterns of the amplified 16S rRNA genes allowed detection of strain SRL $4225^{\mathrm{T}}$, potentially representing a previously unknown species. Cells of strain SRL $4225^{\mathrm{T}}$ were actively motile vibrios occurring singly or in pairs and were $2 \cdot 0-3 \cdot 0 \times 0 \cdot 5 \mu \mathrm{m}$ in size (Fig. 1a).

The same procedure was applied for the isolation of strain 

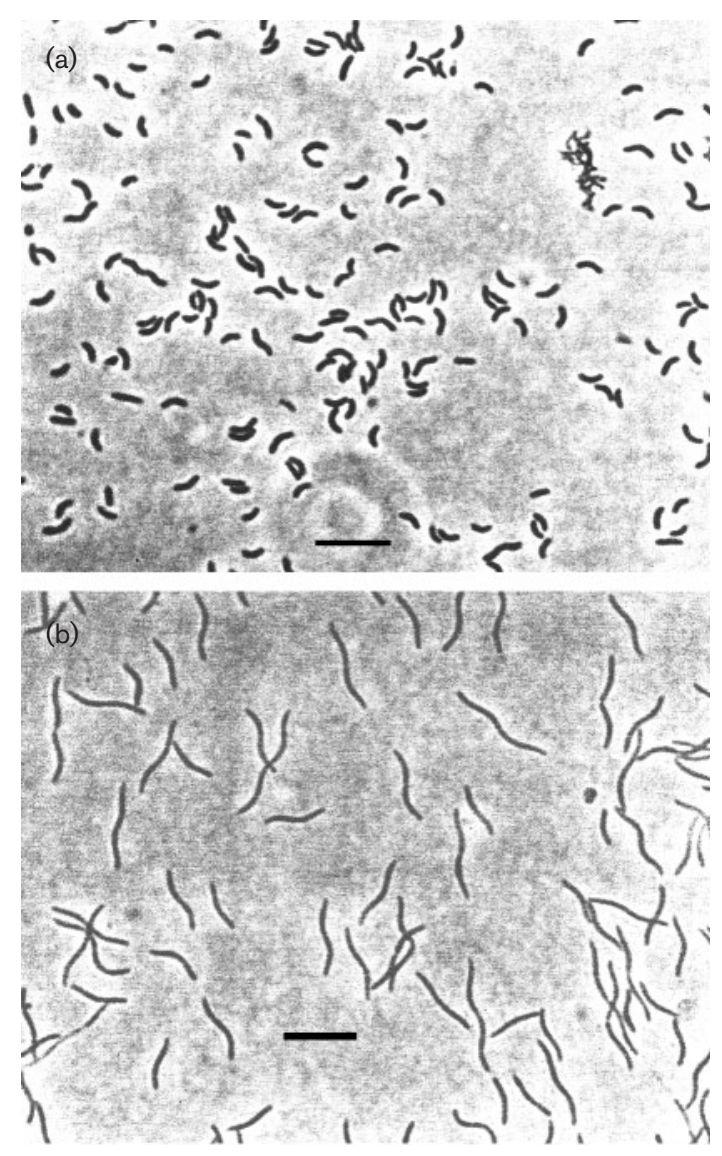

Fig. 1. Phase-contrast micrographs of strains $\mathrm{SRL}_{2} 225^{\top}$ (a) and SRL6146 ${ }^{\top}$ (b). Bars, $5 \mu \mathrm{m}$.

SRL6146 ${ }^{\mathrm{T}}$. It was isolated from an oil and water emulsion collected at production well E153 of Emeraude Oilfield. The water sample contained $2.5 \times 10^{5}$ bacteria $\mathrm{ml}^{-1}$ (acridine orange direct count), from which $9 \cdot 5 \times 10^{3}$ sulfate-reducing bacteria $\mathrm{ml}^{-1}$ were cultivated. Cells of strain SRL6146 ${ }^{\mathrm{T}}$ were long, thin, motile curved or vibrioid cells, 4.5-9.0 $0 \times 0 \cdot 3 \mu \mathrm{m}$ in size (Fig. 1b).

Electron microscopic observations indicated that cells of both strains were motile by means of a single polar flagellum (not shown). Gram staining of both strains was negative.

The physiological and metabolic characterization of the strains included tests to determine utilization of different carbon substrates and energy sources, utilization of a variety of electron acceptors, fermentative growth, temperature, $\mathrm{pH}$ and salinity optima, vitamin requirements and pigment content; the tests used have been described previously (Magot et al., 1992; Tardy-Jacquenod et al., 1996).

The energy and carbon sources used by SRL4225 ${ }^{\mathrm{T}}$ and SRL6146 ${ }^{\mathrm{T}}$ are shown in Table 1 and indicate that both isolates used a rather limited number of substrates. After five transfers, neither strain grew in the absence of vitamins or yeast extract.
Spectra of cell extracts of SRL4225 $5^{\mathrm{T}}$ and SRL6146 ${ }^{\mathrm{T}}$ both exhibited the characteristic absorption band of desulfoviridin at $631 \cdot 5 \mathrm{~nm}$.

Both strains are moderately halophilic bacteria displaying a similar salt requirement that is in agreement with the salinity of their oilfield-water habitat (Table 1). Strain SRL4225 $5^{\mathrm{T}}$ can grow between $\mathrm{pH} 5 \cdot 2$ and $7 \cdot 4$, with an optimum at $\mathrm{pH} 5 \cdot 8-6 \cdot 2$ : such tolerance of low $\mathrm{pH}$ is uncommon among sulfate-reducing bacteria. According to these characteristics, this strain can be considered as a moderately acidophilic sulfate-reducing bacterium, a physiological description that corresponds with the $\mathrm{pH}$ of Emeraude Oilfield water in situ (pH 5.5-6.5), but which is quite uncommon in this bacterial group.

The optimum temperatures for growth of both strains (see descriptions of the species) are also in accordance with the in situ temperature, which varies from 35 to $42^{\circ} \mathrm{C}$ in the different production zones of the oilfield.

Under optimal conditions with lactate as electron donor and sulfate as electron acceptor, the doubling times of strains SRL4225 $5^{\mathrm{T}}$ and SRL6146 ${ }^{\mathrm{T}}$ were 15 and $22 \mathrm{~h}$, respectively.

Determination of the $\mathrm{G}+\mathrm{C}$ content of the DNA of strains SRL4225 ${ }^{\mathrm{T}}$ and SRL6146 ${ }^{\mathrm{T}}$ was done by the Identification Service of the Deutsche Sammlung von Mikroorganismen und Zellkulturen, Braunschweig, Germany. The results are reported in Table 1.

The 16S rRNA genes of SRL4225 ${ }^{\mathrm{T}}$ and SRL6146 ${ }^{\mathrm{T}}$ were amplified and their sequences determined and analysed as previously described (Tardy-Jacquenod et al., 1996). A new sequence of the 16S rRNA gene of Desulfovibrio longus DSM $6739^{\mathrm{T}}$ was determined, for the purpose of this work, by using the same procedure.

The results of FASTA analysis of the 1416-nt 16S rRNA gene sequence of strain SRL4225 ${ }^{\mathrm{T}}$ against sequences in GenBank, and the construction of a phylogenetic tree as previously described (Tardy-Jacquenod et al., 1996), revealed that strain SRL4225 ${ }^{\mathrm{T}}$ forms a distinct cluster with the undescribed Desulfovibrio species strain ASPO3 (93.6\% similarity, distance matrix value), Desulfovibrio hydrothermalis (92.6\%), Desulfovibrio salexigens (91.8\%) and Desulfovibrio zosterae (91.7\%) (Fig. 2). These results suggested that SRL4225 $5^{\mathrm{T}}$ could represent a novel species within the genus Desulfovibrio, although many of its characteristics (except its $\mathrm{pH}$ tolerance) overlap with those of known Desulfovibrio strains.

The 1476 nt $16 \mathrm{~S}$ rRNA gene sequence of strain SRL6146 ${ }^{\mathrm{T}}$ is more closely related $(98.6 \%$ similarity) to that of the undescribed Desulfovibrio sp. strain LVform6 isolated from carbonate sediments (Van Lith et al., 2003), and to the recently described species 'Desulfovibrio capillatus' $(98.2 \%$ similarity), isolated from an oilfield separator (Miranda-Tello et al., 2003). Since it is also closely related to Desulfovibrio longus ( $97 \cdot 5 \%$ similarity), the results of 
Table 1. Discriminating characteristics between strains SRL4225 ${ }^{\top}$ and SRL6146 ${ }^{\top}$, halophilic desulfovibrios and other related Desulfovibrio species

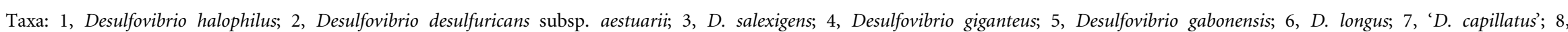

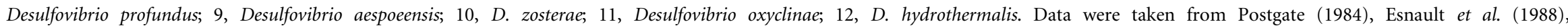

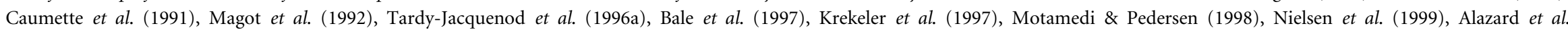

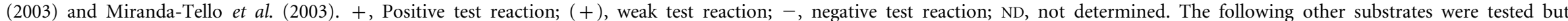

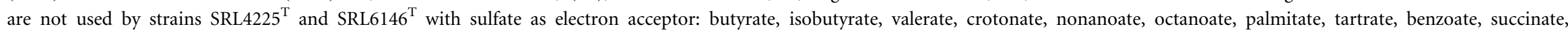

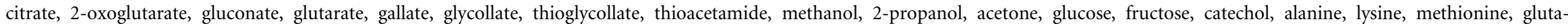

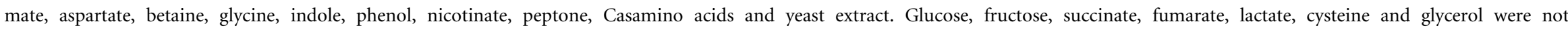

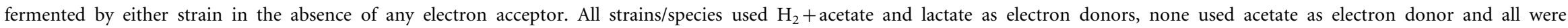
able to ferment sulfate.

\begin{tabular}{|c|c|c|c|c|c|c|c|c|c|c|c|c|c|c|}
\hline Characteristic & 1 & 2 & 3 & 4 & 5 & 6 & 7 & 8 & 9 & 10 & 11 & 12 & SRL4225 ${ }^{\mathrm{T}}$ & SRL6146 ${ }^{\mathrm{T}}$ \\
\hline Morphology & Vibrios & Vibrios & Vibrios & $\begin{array}{l}\text { Curved } \\
\text { rods }\end{array}$ & $\begin{array}{l}\text { Curved } \\
\text { rods }\end{array}$ & $\begin{array}{l}\text { Long, thin } \\
\text { vibrios }\end{array}$ & Vibrios & Vibrios & Vibrios & $\begin{array}{l}\text { Curved } \\
\text { rods }\end{array}$ & $\begin{array}{l}\text { Rods, } \\
\text { curved rods }\end{array}$ & Vibrios & Vibrios & $\begin{array}{l}\text { Long, } \\
\text { thin vibrios }\end{array}$ \\
\hline \multirow[t]{2}{*}{ Size $(\mu \mathrm{m})$} & $0 \cdot 6 \times$ & $0 \cdot 5-1 \times$ & $0 \cdot 5-1 \times$ & $1 \times 5-10$ & $0 \cdot 4 \times$ & $0 \cdot 4-0 \cdot 5 \times$ & $0 \cdot 2 \times$ & $0 \cdot 5-1 \times$ & $0 \cdot 5 \times$ & $0 \cdot 5 \times 3 \cdot 0$ & $0 \cdot 5 \times 2 \cdot 3$ & $0 \cdot 5-1 \cdot 2 \times$ & $0 \cdot 5 \times 2-3$ & $0 \cdot 3 \times 4 \cdot 5-9$ \\
\hline & $2 \cdot 5-5$ & $3-5$ & $3 \cdot 5$ & & $2-4$ & 5-10 & $1-2$ & $1-2$ & $1 \cdot 7-2 \cdot 5$ & & & $1-2$ & & \\
\hline Salinity range $\left(\mathrm{g} \mathrm{l}^{-1}\right)$ & $30-180$ & $5-60$ & $5-120$ & $2-50$ & $10-170$ & 8 & $5-100$ & $6-100$ & $0-30$ & $0-35$ & $25-225$ & Up to 40 & $10-120$ & $20-120$ \\
\hline Salinity optimum $\left(\mathrm{g} \mathrm{l}^{-1}\right)$ & $60-70$ & 25 & $20-40$ & $2-25$ & $50-60$ & $10-20$ & 30 & $10-80$ & 7 & 12 & $50-100$ & 25 & 40 & $50-60$ \\
\hline $\begin{array}{l}\text { DNA G+C content } \\
(\mathrm{mol} \%)\end{array}$ & $60 \cdot 7$ & ND & $46-49$ & $55 \cdot 5$ & $59 \cdot 5$ & $62 \cdot 3$ & $58 \cdot 7$ & 53 & 61 & $42 \cdot 7$ & $\mathrm{ND}$ & 47 & $44 \cdot 6$ & $59 \cdot 0$ \\
\hline \multicolumn{15}{|l|}{ Electron donors } \\
\hline $\mathrm{H}_{2}+\mathrm{CO}_{2}$ & - & - & - & - & - & - & - & $(+)$ & ND & - & - & - & - & - \\
\hline Pyruvate & + & + & + & + & + & + & + & + & ND & + & + & + & + & + \\
\hline Malate & - & + & - & - & + & - & - & - & + & + & + & + & - & - \\
\hline Fumarate & - & + & + & - & + & - & - & - & - & + & - & + & - & - \\
\hline Formate + acetate & + & + & - & + & + & + & - & ND & ND & $(+)$ & + & + & - & + \\
\hline Propionate & - & - & - & - & - & - & - & - & ND & - & - & - & - & - \\
\hline Ethanol & + & + & - & + & + & - & - & - & - & + & + & + & + & - \\
\hline Butanol & - & + & - & + & $(+)$ & - & - & ND & ND & ND & + & ND & + & - \\
\hline Glycerol & - & - & - & + & - & - & - & ND & ND & ND & ND & + & + & - \\
\hline Cysteine & - & - & - & + & - & - & ND & - & ND & ND & ND & ND & - & - \\
\hline \multicolumn{15}{|l|}{ Fermentation of: } \\
\hline Pyruvate & - & + & - & + & + & - & + & + & + & + & + & + & + & - \\
\hline Malate & - & - & - & - & + & - & - & $\mathrm{ND}$ & ND & $\mathrm{ND}$ & $\mathrm{ND}$ & ND & - & - \\
\hline \multicolumn{15}{|l|}{ Electron acceptors } \\
\hline Sulfite & + & + & ND & + & + & + & + & + & ND & + & + & + & + & + \\
\hline Thiosulfate & + & + & $\mathrm{ND}$ & + & + & + & + & - & + & + & + & + & + & + \\
\hline Sulfur & $(+)$ & $(+)$ & $\mathrm{ND}$ & - & + & + & + & - & + & + & + & - & + & + \\
\hline Nitrate & - & + & $\mathrm{ND}$ & - & - & - & - & + & - & - & - & - & - & - \\
\hline Fumarate & - & - & ND & - & ND & + & - & $(+)$ & ND & ND & + & ND & - & + \\
\hline
\end{tabular}




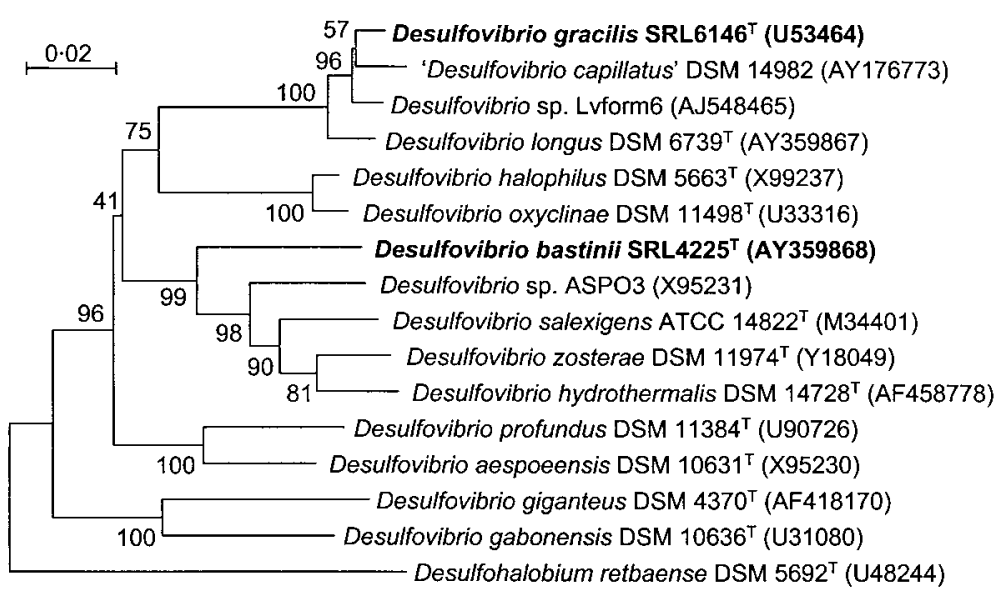

Fig. 2. Unrooted phylogenetic tree based on 16S rRNA gene sequence comparison (1217 conserved positions) indicating the position of strains SRL4225 ${ }^{\top}$ and SRL6146 ${ }^{\top}$ among related members of the genus Desulfovibrio. Bootstrap values, expressed as percentages of 1000 replications, are shown at the nodes. Bar, 2 nucleotide substitutions per 100 nucleotides.
DNA-DNA reassociation experiments, done by the Identification Service of the Deutsche Sammlung von Mikroorganismen und Zellkulturen, were analysed to assess the species status of SRL6146 ${ }^{\mathrm{T}}$. The relatedness between SRL6146 $^{\mathrm{T}}$ and D. longus $(23 \cdot 1 \%$; this study) and that between SRL6146 ${ }^{\mathrm{T}}$ and ' $D$. capillatus' (28.6\%; MirandaTello et al., 2003) clearly indicated that the three strains represent three distinct species.

Thus, SRL6146 ${ }^{\mathrm{T}}$, D. longus and 'D. capillatus' form a distinct cluster of closely related bacteria isolated from oilfield waters. Strain SRL6146 ${ }^{\mathrm{T}}$ closely resembles D. longus in terms of its morphological, physiological and biochemical characteristics. Apart from the $3.3 \mathrm{~mol} \%$ difference in the $\mathrm{G}+\mathrm{C}$ contents of their DNAs, the main difference between these species lies in their salt tolerance. SRL6146 ${ }^{\mathrm{T}}$ is a true moderately halophilic bacterium, since it requires at least $20 \mathrm{~g} \mathrm{NaCl} \mathrm{l}^{-1}$, whereas $D$. longus can grow in the absence of salt (Table 1). This major physiological difference is also reflected by the upper limit of salt tolerance of $120 \mathrm{~g} \mathrm{l}^{-1}$, as opposed to $80 \mathrm{~g} \mathrm{l}^{-1}$ for $D$. longus, and its optimum salinity of 50-60 $\mathrm{g} \mathrm{NaCl} \mathrm{l}^{-1}$, which compares with 10-20 $\mathrm{g} \mathrm{l}^{-1}$ for D. longus.

SRL6146 ${ }^{\mathrm{T}}$ is phenotypically different from the other related species, 'D. capillatus' (Miranda-Tello et al., 2003). These two bacteria differ in morphology, use different electron donors, differ in the fermentation of pyruvate and differ in the use of fumarate as electron acceptor (Table 1).

On the basis of these observations, we propose to assign strains SRL4225 ${ }^{\mathrm{T}}$ and SRL6146 ${ }^{\mathrm{T}}$ to the genus Desulfovibrio as novel species, Desulfovibrio bastinii sp. nov. and Desulfovibrio gracilis sp. nov., respectively.

The two novel bacterial strains isolated during this work display several characteristics that suggest that they might be indigenous to the oil reservoir. Their moderately halophilic character, with optimal salinities for growth between 40 and $60 \mathrm{~g} \mathrm{l}^{-1}$, correspond perfectly to the in situ water salinity of $53 \mathrm{~g} \mathrm{l}^{-1}$. In addition, the optimal growth temperatures and $\mathrm{pH}$ values are in good agreement with the physico-chemical conditions prevailing in the reservoir, i.e. $37-42^{\circ} \mathrm{C}$ and $\mathrm{pH} 5 \cdot 5-6 \cdot 5$. For these reasons, we consider that SRL4225 $5^{\mathrm{T}}$ and SRL6146 ${ }^{\mathrm{T}}$ represent novel bacterial strains originating from a deep subsurface environment (Magot et al., 2000).

\section{Description of Desulfovibrio bastinii sp. nov.}

Desulfovibrio bastinii (bas.ti'ni.i. N.L. gen. n. bastinii of Bastin, named after the American microbiologist Edson S. Bastin, who studied sulfate-reducing bacteria from oilfields at the beginning of the 20th century).

Cells are vibrioid, $0.5 \times 2-3 \mu \mathrm{m}$, occur singly or in pairs and are motile by means of a single polar flagellum. Gramnegative and non-spore-forming. Colonies are round with entire edges, smooth, and grey to dark grey. Moderately halophilic. Optimal $\mathrm{NaCl}$ concentration for growth is $40 \mathrm{~g} \mathrm{l}^{-1}$; growth occurs between 10 and $120 \mathrm{~g} \mathrm{NaCl} \mathrm{l}^{-1}$. Mesophilic. Optimal growth temperature is $35-40^{\circ} \mathrm{C}$; range for growth is $20-50{ }^{\circ} \mathrm{C}$. Moderately acidophilic. $\mathrm{pH}$ range is $5 \cdot 2-7 \cdot 4$; optimum is $\mathrm{pH} 5 \cdot 8-6 \cdot 2$. Vitamins are required for growth. Strictly anaerobic. Sulfate, sulfite, thiosulfate and elemental sulfur serve as electron acceptors, whereas nitrate and fumarate do not. No autotrophic growth. Lactate, pyruvate, malate, fumarate, ethanol, butanol, glycerol and hydrogen in the presence of acetate are used as growth substrates. Lactate is oxidized to acetate and $\mathrm{CO}_{2}$. Pyruvate is fermented. Desulfoviridin is present. The $\mathrm{G}+\mathrm{C}$ content of the DNA is $44 \cdot 6 \mathrm{~mol} \%$.

The type strain is SRL4225 $5^{\mathrm{T}}\left(=\mathrm{DSM} 16055^{\mathrm{T}}=\right.$ ATCC BAA- $\left.903^{\mathrm{T}}\right)$, isolated from oilfield production water collected from a pipeline of Emeraude Oilfield, Congo.

\section{Description of Desulfovibrio gracilis sp. nov.}

Desulfovibrio gracilis (gra'cil.is. L. masc. adj. gracilis slim, slender, thin).

Cells are rod-shaped, $0 \cdot 3 \times 4 \cdot 5-9 \cdot 0 \mu \mathrm{m}$, straight, curved or vibrioid and thin, occur singly and are motile by means of a single polar flagellum. Gram-negative and non 
spore-forming. Colonies are round with entire edges, smooth and grey to dark grey. Moderately halophilic. Optimal $\mathrm{NaCl}$ concentration for growth is $50-60 \mathrm{~g} \mathrm{l}^{-1}$; growth occurs between 20 and $120 \mathrm{~g} \mathrm{NaCl}^{-1}$. Mesophilic. Optimal growth temperature is $37-40{ }^{\circ} \mathrm{C}$; range for growth is $20-40^{\circ} \mathrm{C}$. $\mathrm{pH}$ range is $5 \cdot 4-8 \cdot 4$; optimum is $\mathrm{pH} 6 \cdot 8-7 \cdot 2$. Vitamins are required for growth. Strictly anaerobic. Sulfate, sulfite, thiosulfate, elemental sulfur and fumarate serve as electron acceptors; nitrate is not used. No autotrophic growth. Lactate and pyruvate are used as growth substrates. Lactate is oxidized to acetate and $\mathrm{CO}_{2}$. Fumarate and hydrogen are used in the presence of acetate. Glucose, fructose, succinate, malate, fumarate, pyruvate, lactate, cysteine and glycerol are not fermented. Desulfoviridin is present. The $\mathrm{G}+\mathrm{C}$ content of the DNA is $59 \cdot 0 \mathrm{~mol} \%$.

The type strain is SRL6146 ${ }^{\mathrm{T}}\left(=\mathrm{DSM} 16080^{\mathrm{T}}=\mathrm{ATCC}\right.$ BAA- $904^{\mathrm{T}}$ ), isolated from oilfield production water collected at the E153 wellhead of Emeraude Oilfield, Congo.

\section{Acknowledgements}

Part of this work was supported by a grant from ELF-Aquitaine. We greatly thank F. Laigret for the determination of the $16 \mathrm{~S}$ rDNA sequence of strain SRL6146 ${ }^{\mathrm{T}}$.

\section{References}

Alazard, D., Dukan, S., Urios, A., Verhé, F., Bouabida, N., Morel, F. Thomas, P., Garcia, J.-L. \& Ollivier, B. (2003). Desulfovibrio hydrothermalis sp. nov., a novel sulfate-reducing bacterium isolated from hydrothermal vents. Int J Syst Evol Microbiol 53, 173-178.

Bale, S. J., Goodman, K., Rochelle, P. A., Marchesi, J. R., Fry, J. C., Weightman, A. J. \& Parkes, R. J. (1997). Desulfovibrio profundus sp. nov., a novel barophilic sulfate-reducing bacterium from deep sediment layers in the Japan Sea. Int J Syst Bacteriol 47, 515-521.

Caumette, P., Cohen, Y. \& Matheron, R. (1991). Isolation and characterization of Desulfovibrio halophilus sp. nov., a halophilic sulfate-reducing bacterium isolated from Solar Lake (Sinai). Syst Appl Microbiol 14, 33-38.

Crolet, J.-L. \& Magot, M. (1996). Non-SRB sulfidogenic bacteria in oilfield production facilities. Mater Perform 35, 60-64.

Esnault, G., Caumette, P. \& Garcia, J.-L. (1988). Characterization of Desulfovibrio giganteus sp. nov., a sulfate-reducing bacterium isolated from a brackish coastal lagoon. Syst Appl Microbiol 10, 147-151.

Krekeler, D., Sigalevich, P., Teske, A., Cypionka, H. \& Cohen, Y. (1997). A sulfate-reducing bacterium from the oxic layer of a microbial mat from Solar Lake (Sinai), Desulfovibrio oxyclinae sp. nov. Arch Microbiol 167, 369-375.
Magot, M., Caumette, P., Desperrier, J. M., Matheron, R., Dauga, C., Grimont, F. \& Carreau, L. (1992). Desulfovibrio longus sp. nov., a sulfate-reducing bacterium isolated from an oil-producing well. Int J Syst Bacteriol 42, 398-403.

Magot, M., Fardeau, M.-L., Arnauld, O., Lanau, C., Ollivier, B., Thomas, P. \& Patel, B. K. C. (1997a). Spirochaeta smaragdinae sp. nov., a new mesophilic strictly anaerobic spirochete from an oilfield. FEMS Microbiol Lett 155, 185-191.

Magot, M., Ravot, G., Campaignolle, X., Ollivier, B., Patel, B. K. C., Fardeau, M.-L., Thomas, P., Crolet, J.-L. \& Garcia, J.-L. (1997b). Dethiosulfovibrio peptidovorans gen. nov., sp. nov., a new anaerobic, slightly halophilic, thiosulfate-reducing bacterium from corroding offshore oil wells. Int J Syst Bacteriol 47, 818-824.

Magot, M., Ollivier, B. \& Patel, B. K. C. (2000). Microbiology of petroleum reservoirs. Antonie van Leeuwenhoek 77, 103-116.

Miranda-Tello, E., Fardeau, M.-L., Fernández, L., Ramirez, F., Cayol, J.-L., Thomas, P., Garcia, J.-L. \& Ollivier, B. (2003). Desulfovibrio capillatus sp. nov., a novel sulfate-reducing bacterium isolated from an oil field separator located in the Gulf of Mexico. Anaerobe 9, 97-103.

Motamedi, M. \& Pedersen, K. (1998). Desulfovibrio aespoeensis sp. nov., a mesophilic sulfate-reducing bacterium from deep groundwater at Äspö hard rock laboratory, Sweden. Int J Syst Bacteriol 48, 311-315.

Nielsen, J. T., Liesack, W. \& Finster, K. (1999). Desulfovibrio zosterae sp. nov., a new sulfate reducer isolated from surface-sterilized roots of the seagrass Zostera marina. Int J Syst Bacteriol 49, 859-865.

Ollivier, B., Cayol, J.-L., Patel, B. K. C., Magot, M., Fardeau, M.-L. \& Garcia, J.-L. (1997). Methanoplanus petrolearius sp. nov., a novel methanogenic bacterium from an oil producing well. FEMS Microbiol Lett 147, 51-56.

Postgate, J. R. (1984). Genus Desulfovibrio Kluyver and van Niel 1936, 397 ${ }^{\mathrm{AL}}$. In Bergey's Manual of Systematic Bacteriology, vol. 1, pp. 666-672. Edited by N. R. Krieg \& J. G. Holt. Baltimore: Williams \& Wilkins.

Ravot, G., Magot, M., Ollivier, B., Patel, B. K. C., Ageron, E., Grimont, P. A. D., Thomas, P. \& Garcia, J.-L. (1997). Haloanaerobium congolense sp. nov., an anaerobic, moderately halophilic, thiosulfateand sulfur-reducing bacterium from an African oilfield. FEMS Microbiol Lett 147, 81-88.

Ravot, G., Magot, M., Fardeau, M.-L., Patel, B. K. C., Thomas, P., Garcia, J.-L. \& Ollivier, B. (1999). Fusibacter paucivorans gen. nov., sp. nov., an anaerobic, thiosulfate-reducing bacterium from an oilproducing well. Int J Syst Bacteriol 49, 1141-1147.

Tardy-Jacquenod, C., Magot, M., Laigret, F., Kaghad, M., Patel, B. K. C., Guezennec, J., Matheron, R. \& Caumette, P. (1996). Desulfovibrio gabonensis sp. nov., a new moderately halophilic sulfate-reducing bacterium isolated from an oil pipeline. Int J Syst Bacteriol 46, 710-715.

Van Lith, Y., Warthmann, R., Vasconcelos, C. \& McKenzie, J. A. (2003). Microbial fossilization in carbonate sediments: a result of the bacterial surface involvement in dolomoite precipitation. Sedimentology 50, 237-245. 